\title{
Result-Based Management in the Public Sector: A Decade of Experience for the Tanzanian Executive Agencies
}

\author{
Andrew Sulle \\ Mzumbe University, Dar es Salaam, Tanzania. \\ E-mail: sullea@yahoo.co.uk \\ Received June $7^{\text {th }}$, 2011; revised August $3^{\text {rd }}, 2011$; accepted September $2^{\text {nd }}, 2011$.

\begin{abstract}
One element of the NPM-inspired reforms is the adoption of result-based management in the Tanzanian public sector. This paper examines the implementation of this type of reform by focusing on executive agencies. Executive agencies were especially created to be result-oriented public organizations. Our empirical question is whether or not and to what extent the management of executive agencies has shifted to result-based approach as promised by NPM-reform doctrine. Our findings indicate that result-based approach has only been partially implemented in the Tanzanian public sector. There is less emphasis on managing for results and management processes have continued to be predominantly based on inputs and processes.
\end{abstract}

Keywords: Public Administration, Result-Based Management, NPM, Executive Agencies and Reform in Tanzania

\section{Introduction}

One of the central features of the current public sector reforms is the emphasis on performance results. Managing for results requires the government to focus on the performance outputs/outcomes of its organizations instead of their administrative processes. This new approach has been enthusiastically embraced by many countries [1] following the rise of New Public Management (NPM) doctrine. The NPM doctrines suggest that improving the performance of public services demands a focus on results while providing public managers greater authority over their fiscal and human resources management. In addition, this reform requires political leaders to set out performance objectives and results, determine the level of resources to be used and devolve implementation tasks to low level administrative managers [2,3].

Result-based management approach is clearly related to the NPM reform movement that began initially in the West, notably in Australia, the UK, the US and New Zealand [1]. However, in recent years a number of developing countries have also adopted this approach as a "management tool" to restructure and improve the performance of their public sector organizations [3,4]. In Tanzania, the recent public sector reforms also embraced this management approach. For many developing coun- tries such as Tanzania, the adoption of this reform strategy has been partly based on their inspiration for such reforms in the West. The role of international donors such as the World Bank and IMF in encouraging developing countries to adopt result-based management approach has also been recognized in the literature [4,5]. What is, however, not very clear up until now is whether and to what extent the result-based management approach has been implemented in the Tanzanian public sector. It is now more than ten years since this reform was introduced in Tanzania, and yet little has been documented regarding its success or drawbacks. In the West, Moynihan [1] reports that although there is a widespread adoption of the result-based management reform, definitive empirical evidence on whether these reforms have had desired outcomes were not forthcoming. For Tanzania, our knowledge is even limited as to whether this reform has moved further from the point of adoption ${ }^{1}$. This article examines the introduction and the practice of result-

\footnotetext{
${ }^{1}$ In our study we distinguish between a reform adoption and its implementation. Adoption in our case refers to a situation where reform policy is officially enacted (declared) whereas policy implementation means that reform is actually put to practice. In reality, policy statement (adoption) may never be fully or only partially implemented. Therefore in this sense, a policy adoption can be distinguished from the policy implementation process.
} 
based management in the Tanzanian public sector, using executive agencies as its focal point. Executive agencies operate at arm's length from their parent ministries and by their design, they are task-specific and result-focused public organizations. They are thus ideal organizations for our study. The main aim of the paper is to contribute to our understanding of how result-based management works in practice in Tanzania by addressing the following questions: To what extent is the result-based management practice used in managing agencies? How has it worked in practice?

The paper will proceed as follows. Following the introduction above, the next section provides an overview of the 'managing for results approach'. Its central arguments will be discussed in connection to the current public sector reforms. The subsequent sections provide background to the public sector reforms in Tanzania; data analysis on the implementation of the result-based reform; a discussion and conclusions.

\section{Managing for Results: An Overview}

Since the 1990s, the public sector has globally experienced a tidal wave of reforms that, among other things, focused on performance management. The main focus of this reform brand was managing for results. Moynihan [6] describes management by results as a combination of strategic planning (systems that set organizational goals), performance measurement (systems that track and provide information on cost and accomplishments of government tasks), and some form of strategic/performance management (systems that shape working relationships and structure discretion in a way consistent with organizational goals). The appeal of this approach lies in its promise to enhance the performance of public sector organizations. According to the NPM, the traditional public administration model performs poorly because it lacked explicit standards of performance and that there was no a strong result-based accountability. Proponents of NPM argue that efficiency and effectiveness of public services can be achieved if governments adopt a focus on results while increasingly allowing managerial flexibility for policy implementation [1]. The result-based reform thus seeks to transform public sector into a flexible, dynamic, efficient and mission-driven institution.

Managing for results requires governments to move away from an administrative culture of compliance, error avoidance, rigid rules and procedures, and presumed inefficiency to a more efficient and effective public service management systems. It demands multiple changes to the existing public administrative systems that, for years, were based on the Weberian model [7]. First, the reform seeks to introduce a new role for parent ministries that of being strategic leaders while the task of implementing policies is delegated to professional bureaucrats, a process that can be described as the agencification of public service management [8]. This distribution of work between central ministries and their executive agencies entails decentralization. Following this distribution of roles and responsibilities, a further important element in the implementation of the result-based management is the identification and definition of objectives and indicators of expected performance results [9]. The political leadership (the parent ministry) must formulate clear performance goals and targets to be achieved, and give subordinate bodies a leeway and discretion in achieving these goals. Goals are to be defined in measurable terms that would allow a comparison of ex post performance with exante targets [10]. In addition, the government is obliged to provide enough resources for agencies to accomplish their responsibilities [8].

Result-based management approach can be regarded as a management process that consist of interrelated subsystem [11]: a planning system (setting goals for agencies), a monitoring system (measuring agency performance results) and lastly an evaluation and feedback system (where sanctions and rewards are applied). As Laegreid et al. [10], suggest the emphasis should be given to planning and the measurement of performance results. In addition, parent ministries must use information on reported results to reward good performance and punish bad.

Moreover, central to the NPM reform prescription is the promise of greater efficiency in the public organizations as a result of providing managers with greater freedom to allocate resources, while holding them accountable for results [7]. As a management tool, result-based approach is therefore a double-edged sword. It advocates both centralization and decentralization of public sector management [2]. The argument is that public managers would need some freedom to allocate resources in pursuit of their organizational goals. Line-item budgets should be discarded in favour of global budgets ${ }^{2}$ and that competencies for resources management should be devolved to the agencies $[6,9]$. In the context of the public sector this means that the agency is exempted from centrally determined rules and regulations regarding inputs management [11]. Theoretically, agencies are thus free to make their own decisions on human resources and financial management issues such as recruitment, salary grading, dismissal, promotions, evaluation of performance, and on financial management aspects such as setting tariffs, generating revenues and shifting budgets between

\footnotetext{
${ }^{2}$ In this arrangement, the resources (inputs) for policy delivery are assigned for group of products as lump sum while specification for resources along categories of costs as in detailed resources plan is omitted.
} 
different financial years, and in taking loans for further investment. These elements are traditionally the prerogative of central ministries such as the Civil Service Department and the Ministry of Finance. In the literature [11] the scope of managerial autonomy can further be sub-divided into strategic and operational managerial autonomy. Strategic autonomy is about the agency's power to determine rules that governs human resources while operational autonomy is simply the ability of the agency to confer secondary benefits to its employees [11].

Owing to the intensification of pubic sector reforms in the past years, there is a need for detailed empirical scrutiny of how such reforms have been implemented and to what extent the government of Tanzania has actually shifted the management of its organizations from the Weberian-based model to the result-based approach as advocated by NPM doctrines. As Christensen and Laegreid [2] have argued, while certain reform effects are often promised and expected, they are seldom reliably documented. This study seeks to contribute to the growing body of reform literature by studying the introduction of result-based management in the public sector in Tanzania. This article is of considerable interest to reformers and practitioners. For example, by highlighting the extent to which result-based reforms were implemented or not, political actors may start to take stock of what has not worked and why.

\section{Public Sector Reforms in Tanzania: Towards Result-Based Management System}

The background to the public sector reform in Tanzania is not very much different from that in other countries in Africa. The economic crisis in the 1980s and poor performance of public sector ignited far reaching public sector reforms. The reforms aimed at halting the expansion of the public sector size and to enhance its operational efficiency. For example, since independence up until the 1990s, there has been a steady rise in the number of people recruited in the public sector in Tanzania. As McCourt and Solla [12] noted, the policy of africanization $^{3}$ between 1961 and 1970s saw an increase in a number of civil servants in many professional areas. The situation was further exacerbated by the politicization of civil service especially when Tanzania adopted the socialist policy in 1967. Under socialism, employment in the public sector was rather driven by the socialist ideology and political patronage rather than clear management rationality. This not only compromised the productivity of public sector but it also expanded the size of public service.

\footnotetext{
${ }^{3}$ This was about replacing departing colonial bureaucracy with indigenous Tanzanians.
}

Thus by 1984, more than $72 \%$ of formal sector employment was in public sector, and in 1989 a Report by the World Bank found that between 1970 and 1984, public service employment had expanded at roughly twice the rate of government revenues [12]. In addition, civil service was poorly performing, riddled with corruption, demotivated and lacked the capacity to manage market-led economic policies which the government had embraced in the 1980s [13].

The government of Tanzania officially launched the Civil Service Reform Programme (CSRP) in 1993 with the objective of creating a 'smaller, affordable, well-compensated, efficient and effectively performing civil service' [13]. The reform focused not only on institutional restructuring of the civil service but also in introducing new ideas and techniques in the management of public services. As result of the reform efforts, the government instituted a number of reform measures including the creation of executive agencies that are placed at arm's length from their parent ministries [14].

Executive agencies are an important element of the result-based management system. Agencies can best be described as a tool for "unbundling the traditional bureaucracy" in order to create more flexible, and performance-oriented public organizations [15]. As Caulfield [2] noted, their appeal follows a widespread shift to business-like forms of managing public sector in pursuit of improving efficiency and effectiveness of public service delivery. The creation of agencies with clearly specified, single-purpose tasks will, it is assumed, increase transparency of government operations [2]. In an ideal-agency model, agencification allows for managerial autonomy by decentralizing decision-making competence in all areas of their management (including financial and human resource management) to Chief Executive Officers (CEOs). In turn, the CEO is made accountable for achieving specified results. In general, the relationship between the parent ministry and their agencies is to be regulated through performance contracts than through normal government - wide public sector regulations.

The executive agency programme was officially adopted in Tanzania in 1997. The policy expectation is that agencies will conform to the modern management practices by developing strategic and business plans. Following years of poor performance of the public sector, the agency model was seen as an organizational solution, which would keep public services within the government, while promising efficiency and effectiveness of public service delivery [2]. Since the 1990s executive agencies have been created in various ministries. As of August, 2007 there were 24 executive agencies scattered in different ministries. They perform various public tasks and are formally managed at arm's length by their parent mi- 
nistries. The agency is headed by a CEO, who is recruited through an open competition for a renewable contract of 5 years. According to the agencification policy, parent ministries would set out performance goals, targets and monitor their agencies on the bases of performance results. This reform policy demands ministers and parent ministries in general to refrain from interfering in the day-to-day management of the agencies (The Executive Agency Act no.30.1997). It has been insisted that the role of parent ministries should be limited to that of setting strategic direction for agencies and to ensure that agencies are held accountable for achieving performance results.

Since executive agencies are, by their design, resultfocused organizations, we expect result-based management practice to be more robust. As elaborated earlier, the working relationship between agencies and their parent ministries is expected to be based on performance contracts in which agencies are given more managerial autonomy in return for performance-based accountability. This article seeks to explore to what extent this policy rhetoric has been put to practice in Tanzania.

\section{Data Base}

This study is empirically based on the public sector in Tanzania. Following a review of the current literature on public sector reforms in Tanzania, we draw on a survey questionnaire addressed to the CEO of all 24 executive agencies in Tanzania. This survey was conducted at the beginning of 2008. CEOs were asked to fill in a survey questionnaire covering all aspects related to autonomy, control and the agencies' performance. The response rate was $78 \%$, thus making us conclude that the respondents are quite representative of the population of agencies in Tanzania. In Tanzania all executive agencies are established under a single legislation, the Executive Agency Act, No.30, 1997, and it is thus easy to delineate agencies from other public organizations.

\section{Empirical Findings Results-Based Management in Tanzania}

As elaborated earlier, there are two aspects of the resultbased management approach in general. The first aspect is that of parent ministries setting performance goals for agencies, then monitoring, evaluating and applying sanctions and rewards according to the agencies' performance level. This can be summarised as "making managers manage". The second aspect is that of "letting managers manage". This entails giving agencies more managerial autonomy. In this analysis, we first examine the managerial autonomy of agencies in Tanzania before we present the data on the extent to which agencies are subjected to a result-based control.

\section{Agencies’ Managerial Autonomy}

Empirical findings for the level of agencies' managerial autonomy are provided in Table 1. The table shows both the level of strategic and operational managerial autonomy for agencies. As indicated, executive agencies in Tanzania have less strategic managerial autonomy in human resources and in some aspects of financial management. These data indicate that most agencies, if not all, are not allowed to have their own human resources policy or strategic decisions on vital areas such as employment and salary levels for their employees. The extent of agencies' autonomy is lowest on decisions about salary setting (5.6\%), setting condition for employing new staff (22\%), and in determining the work force size (33.3\%). These strategic managerial elements are still predominantly centrally controlled (Public Service Management and Employment Act, 1999). More specifically, employment needs in the agencies must be approved centrally by the Civil Service Department and the Treasury [16]. This is contrary to the NPM doctrine which requires the elimination of centralized human resources rules and regulations. The aim of the NPM administrative reform was to remove the centralized Weberian rules, which make it hard for public managers to hire, fire, redeploy and set their salary policies according to their circumstances. After a decade of the agencification reforms, the Tanzanian government seems to be reluctant to provide agencies with these key elements of managerial autonomy.

Further more, whereas $77.8 \%$ of agencies responded that they can effect promotion, $88.9 \%$ agree that they can as well evaluate the performance of individual staff. In addition, most agencies (83\%) have gained the freedom to set themselves the level of fees they can charge their customers for the goods and services they produce. There are however, some sensitive public services that the government can not let the agencies to set charges freely, even at the prevailing market price.

For instance, one agency, (TEMESA) runs several ferries in some major rivers, lakes and along the Indian Ocean coast, mainly for the purpose of providing public transport. Despite huge running costs, these ferries still charge the lowest possible fare (eg. US\$ 0.13 per adult for a Dar es Salaam-Kigamboni trip, a distance of about $0.5 \mathrm{~km}$ ) and although the agency may wish to increase that fare, the final decision was still in the hand of the parent ministry. Tanzania Building Agency (TBA) also faces a similar fate. The agency's core task is to build houses, first for public servants and individuals, but it can also sell or let to private firms or individuals. Whereas for private firms and private individuals, the agency has the liberty to set charges according to the prevailing market rates, but with respect to houses for public servants the rate is normally determined by the government. 
Table 1. The level of agencies’ autonomy along various managerial dimensions.

\begin{tabular}{|c|c|c|c|c|c|c|}
\hline \multirow{2}{*}{$\begin{array}{l}\text { Variable: } \\
\text { Autonomy in }\end{array}$} & \multirow{2}{*}{$\begin{array}{l}\text { Measurement: } \\
\text { Whether the agency is allowed do the following }\end{array}$} & \multicolumn{4}{|c|}{ Response from agencies in categories } & \multirow{2}{*}{ Total N- } \\
\hline & & Yes & $\%$ & No & $\%$ & \\
\hline \multirow{4}{*}{$\begin{array}{l}\text { Strategic Human Re- } \\
\text { sources Management }\end{array}$} & 1. Setting salary level & 1 & 5.6 & 17 & 94.4 & 18 \\
\hline & 2. Setting general conditions for promotion & 8 & 44.4 & 10 & 55.6 & 18 \\
\hline & 3. Determining the size of agency (number of staff) & 6 & 33.3 & 12 & 66.7 & 18 \\
\hline & 4. Setting conditions for Employment & 4 & 22 & 14 & 77.8 & 18 \\
\hline \multirow{5}{*}{$\begin{array}{l}\text { Operational Human } \\
\text { Resources Management }\end{array}$} & 1. Rewarding well performing staff & 15 & 83.3 & 3 & 16.7 & 18 \\
\hline & 2. Promoting individual staff & 14 & 77.8 & 4 & 22.2 & 18 \\
\hline & 3. Wage increase for individual staff & 2 & 11.1 & 16 & 88.9 & 18 \\
\hline & 4. Evaluating individual staff & 16 & 88.9 & 2 & 11.1 & 18 \\
\hline & 5. Transferring staff between units within the agency & 17 & 94.4 & 1 & 5.6 & 18 \\
\hline \multirow{5}{*}{$\begin{array}{l}\text { Financial Managerial } \\
\text { Autonomy }\end{array}$} & 1. Taking loans. & 3 & 16.7 & 15 & 83.3 & 18 \\
\hline & 2. Setting tariffs/prices for their goods and services & 15 & 83.3 & 3 & 16.7 & 18 \\
\hline & 3. Participating in private law & 1 & 5.6 & 17 & 94.4 & 18 \\
\hline & 4. Shifting budget between Personnel \& other costs & 2 & 11.1 & 16 & 88.9 & 18 \\
\hline & 5. Shifting funding/budget between different years & 14 & 77.8 & 4 & 22.2 & 18 \\
\hline
\end{tabular}

Source: Survey, 2007.

Following these two examples, it seems that to some extent, in politically sensitive public services, the government may intervene in setting charging rates for agencies' services. It is also worth noting that there is often a general resistance within the government to let agencies charge for services that are "consumed" by government departments. At the launch of the agency programme, the government had anticipated internal markets for agencies' services when it said "agencies will receive income from trading with government departments and other customers". This has turn out to be problematic for agencies, particularly those whose major customers are government ministries and departments. For example, Public Service Report Programme (PSRP 2006) observed that although many agencies would want to charge market-level fees for their products so as to generate revenues, government departments and ministries took a traditional view and resent to pay for services they received from the agencies. Similarly, Caulfield [2] argues that ministries have failed to see why they should pay for the services provided by their units. She also notes that the general public in Tanzania had a trouble of coming to terms with new "user fees" environment. One reason for this could be the legacy of Ujamaa ${ }^{4}$ policy, in which public services were heavily subsided or were provided freely by the government.

\footnotetext{
${ }^{4}$ This is the Tanzanian version of Socialism
}

Agencies seem to have gained considerable discretion over how they can manage their global budgets. As noted in the Table 1, agencies can retain unspent monies and transfer the same budget between different financial years (77\%). They cannot, however, shift budget between personnel and other costs for obvious reasons. In almost all agencies, personnel salary is still paid by the treasury and therefore agencies do not have any discretion over it.

\section{Managing Results for Executive Agencies}

The creation of agencies was expected (theoretically) to result in agencies being controlled by performance results. In principle, control on inputs was supposed to be replaced by a result-based control. Key elements of the result-based control have been identified as goal/objecttive setting together with their quantifiable performance indicators against which the results are measured; the process of performance monitoring and evaluations followed by rewards and sanctions according to the level of performance achieved. In what follows these management aspects are empirically examined.

Our empirical data indicate that parent ministries are not largely involved in setting performance goals and indicators for their agencies. In most cases, executive agencies have been left to develop their own performance objectives. For example, most agencies (83\%) indicated that they set their own performance goals as well as performance targets. Similar observations can also be drawn 
from some previous research. According to Ronsholt and Andrew [17] agencies have been left to develop their own performance target without necessarily getting approval from their parent ministries. In our research we observed that it was only the Tanzania National Roads Agency (TANROADS) whose performance objectives are set by the government through the Ministry of Infrastructure Development and the Road Funds Board ${ }^{5}$. In addition, TANROADS is the only agency that signs annual performance contracts with these two oversight authorities that are jointly responsible for its performance. For example, while all road maintenance works are funded by the Road Funds Board (RFB) the development of new road projects is generally funded by the parent ministry, mainly through donor funds. In this scenario, TANROADS signs two performance contracts annually: one with the parent ministry and other with the Road Funds Board. Each oversight authority develops its own performance goals for TANROADS and then monitors the implementation. The reason why the government was interested in the performance of this agency is beyond the scope of this work.

Another aspect of result-based management approach is the presence of performance indicators that would help political leadership to evaluate how agencies have achieved their performance objectives. In the UK, these are called the minister's performance indicators and they are developed by the parent ministry [2]. In Tanzania, parent ministries are not generally involved in developing performance indicators for their agencies. As part of their annual business plans, agencies develop their own performance indicators and these business plans are discussed during the annual meetings of the Ministerial Advisory Boards (MAB). In addition, agencies also evaluate their own performance (50\%) and only a few (38\%) said that their respective parent ministries do evaluate their performance. In Tanzania, the notion of monitoring the performance of executive agencies through the process of measuring and evaluating results is poorly developed. Ronsholt and Andrew [17] also noted a real lack of parent ministries in developing indicators and in monitoring the performance of agencies. According to them the real interest of parent ministries is to extract financial surplus from their agencies than to see how agencies performing their tasks. Earlier Caulfield [2] also noted a serious lack of performance monitoring for agencies in Tanzania: no parent ministry we visited has a performance monitoring regime in place...there have been no pressure on the agencies to produce an annual reports.

\footnotetext{
${ }^{5}$ This is a special and dedicated Fund established by the Act of Parliament to ensure that Roads works have a stable and identifiable source of funding. The Fund mainly receives its revenue from fuel levy taxed for every litre of petrol sold at a pump in the country.
}

Indeed, result-based accountability was supposed to be linked to clear incentives for results and possibly sanctions for bad performance [6]. Yet, our empirical data indicate that Tanzania is lagging behind in implementing this reform aspect. The overall picture from our analysis is that sanctions and rewards are not strongly emphasized in the management of agencies. First, if parent ministries are, as we have already seen, less interested in setting performance objectives for agencies and are not doing actual evaluation of their agencies' performance, there is no strong way the government can reward good performance and punish the bad ones. Improved information about the performance of agencies could have been used to allocate praise or blame, and indeed the same can be used to inform decisions about resources allocation to agencies including their staffing levels. In Tanzania these monitoring elements are not emphasized in managing the agencies.

\section{Concluding Discussion}

The main focus of this article was on the implementation of the result-based management in Tanzania by focusing on the executive agencies. Informed by NPM ideas the initial assumption was that agencies would be managed on the basis of results and that their managerial autonomy will be enhanced. When the agencification programme was introduced in Tanzania in the 1990s the official rhetoric was to move away from inputs and process focused-management approach to outputs-based management approach [14]. The policy intention of the agencification reform was to dis-bundle monolithic traditional bureaucracies into tasks specific and results-focused agencies that are to be given more managerial autonomy in delivering public services within a prescribed resources and performance accountability. It was insisted that parent ministries would set strategic direction and performance objectives for their agencies while monitoring them on the basis of performance outputs (Executive Agency Act, No.30, 1997). Instead of hierarchical control, the agency model was formed on the precepts of principal-agent model where the relationship between agencies and their parent ministries was to be moderated through performance contracts.

As demonstrated, our main finding in this research is that the government of Tanzania has continued to manage executive agencies mainly on the basis of the Weberian model (inputs and processes), than the expected result-based control. Although the NPM doctrine calls for the creation of performance-based accountability while dismantling traditional financial and personnel control systems, this has not been fully embraced in Tanzania. The traditional civil services systems have remain largely in place in managing agencies, and the government has 
even continued to enforce this approach, sometimes through legislation (Public Service Management and Employment Policy, 1999). This Policy, although developed at a time when policy makers in Tanzania were already aware of the basics of the NPM doctrine, has further centralized and placed the management of Civil Service in the hands of PO-PSM. The PO-PSM (the Civil Service Department) has retained its traditional power to formulate, review and evaluate human resources policies in the entire public service, leaving line ministries and agencies with very little freedom [16].This contrasts the NPM's philosophy of giving agencies more autonomy to manage their staff in a businesslike way. While NPM ideas seem to have been able to partially influence structural reforms (we mean the process of putting agencies at arm's length from their parent ministries), this reform process was not able to break the institutional thinking and thus the process of controlling agencies. The preference for hierarchical control, which is embedded in the management of public sector in Tanzania, is most visible when we look at the agencies' managerial autonomy. Most agencies display low strategic managerial autonomy. Agencies still need prior approval from their parent ministries and indeed from central ministries such as the PO-PSM and the Treasury for most of the HRM and financial management. Within the agencies, the tradition of financial audit also seems to be more dominant than the result-based audit, which is encouraged by the NPM doctrines so as to achieve the so called 'value for money' [18].

It was also striking to note a general absence of the strategic steering by ministries as envisaged by NPM doctrines. According to NPM reform doctrine elected officials or parent ministries would set the goals and hold bureaucrats accountable for achieving those goals [6]. This promise, has however, not been fulfilled in Tanzania. As noted earlier, the task of developing performance goals was mainly left to agencies themselves and in many instances agencies have taken themselves a lead in evaluating their own performance. In her research in 2002, Janice Caulfield also reported the same observations. She noted that... most agencies have been left to develop their own operational targets without necessarily even getting formal approval from their parent ministries about what they should be. Moreover, Permanent Secretaries appear to be unsure about their role as strategic managers and that parent ministries were disinterred in monitoring and evaluating agencies performance. This paper's observation is not dissimilar. Agencies face a weak result-based control. Performance monitoring and evaluation are weak and performance results plans are poorly developed. To some extent, parent ministry's interest was in the financial performance. In this regard, one senior manager has this to say 'since Permanent Se- cretary is the accounting officer in the ministry, financial management in the agencies is of great interest to him to avoid public or Parliamentaty Committee queries for any misuse of funds in the agencies' [18].

Furthermore, in the ideal-NPM agency model, it is the contractual relationship which provides the link between agencies and their parent ministries. In Tanzania the pattern of control is rather complex and the tools of governing agencies are somehow ambiguous. There is much use of traditional bureaucratic mechanisms in controlling agencies, but these are also not used in any systematic and sophisticated way. Our general conclusion is that the agencification reform in Tanzania has not resulted in a shift from the traditional (Weberian) approach to the resultbased approach as envisioned in the NPM doctrines. Both agencies' autonomy and result-control are weak when examined from the NPM perspectives. Management of public human resources in Tanzania is politically salient and may not be easily delegated to the agencies. It involves both resources and patronage distribution in the public sector, things that are politically sensitive. As a result the finding in this paper suggests that the resultbased control has only been partially introduced in Tanzania.

\section{Further Research}

This research paper is generally a descriptive analysis of the implementation of the result-based management reform for the executive agencies in Tanzania. It highlighted the limited implementation of the reform without delving into the question of why reform has not been successfully implemented. Further research could address the question of why this reform has only been partially implemented in Tanzania. Such research could be done from many interesting theoretical perspectives. For example, one important argument in the literature is that most developing countries do no have the required administrative capacity to implement sophisticated administrative reforms based on NPM ideas [19]. Likewise, others have suggested that most NPM ideas are somehow incompatible with administrative cultures of most developing countries [20]. These factors may shed light into the question of why NPM reform elements such as the result-based management approach has failed to take root in the Tanzanian public sector.

\section{REFERENCES}

[1] D. D. Moynihan, "Managing for Results in State Government: Evaluating a Decade of Reform," Public Administration Review, 2006.

[2] T. Christensen and P. Laegreid, "Regulatory AgenciesThe Challenges of Balancing Agency Autonomy and Political Control," Governance, Vol. 20, No. 3, 2007, pp. 
499-520. doi:10.1111/j.1468-0491.2007.00368.x

[3] J. Caulfield, "Executive Agencies in Tanzania: Liberalization and Third World Debit," Public Administration and Development, Vol. 22, No. 200, pp. 2209-2220.

[4] G. Larbi, "Performance Contracting in Practice; Experience and Lessons from the Water sector in Ghana," Public Management Review, Vol. 3, No. 3, pp. 305-324. doi:10.1080/14616670110044018

[5] C. Polidano, "Why Civil Service Reforms Fail; IDPM Public Policy and Management,” Working Paper no.16. 2001.

[6] D. Moynihan, "Why and How Do State Governments Adopt and Implement Managing for Results Reforms? Journal of Public Administration Research and Theory, Vol. l, No. 15, 2005, pp. 219-243.

[7] R. Norman and R. Gregory, "Paradoxes and Pendulum Swings: Performance Management in New Zealand's Public Sector," Australian Journal of Public Administration, Vol. 62, No. 4, 2003, pp. 35-49. doi:10.1111/j..2003.00347.x

[8] M. Tiili, "Strategic Political Steering: Exploring the Qualitative Change in the Role of Ministers after NPM reforms," International Review of Administrative Science, Vol. 73, No. 81, 2007, pp. 81-94. doi:10.1177/0020852307075691

[9] I. Proeller, “Outcome-Orientation in Performance Contracts: Empirical Evidence Rom Swiss Local Governments," International Review of Administrative Sciences, Vol. 73, 2007, pp. 95-110. doi:10.1177/0020852307075692

[10] P. Lægreid, P. Roness and K. Rubecksen, "Performance Management In Practice: He Norwegian Way, Financial Accountability \& Management, Vol. 22, No. 3, 2006, pp. 251-270. doi:10.1111/j.0267-4424.2006.00402.x

[11] K. Verhoest, B. Peters, G. Bouckaert and B. Verschuere, "The Study of Organizational Autonomy: A Conceptual Review,” Public Administration and Development, Vol.
24, 2004, pp. 101-118. doi:10.1002/pad.316

[12] W. McCourt and N. Solla, "Using Training to Promote Civil Service Reform: A Tanzanian Local Government Case Study," Public Administration and Development, Vol. 19, 1999, pp. 21-32. doi:10.1002/(SICI)1099-162X(199902)19:1<63::AID-PA D55>3.3.CO;2-6

[13] D. Ntukumazina, "Civil Service Reform in Tanzania: A Strategic Approach,” In S. Rugumamu, Ed., Civil Service Reform In Tanzania: Proceedings of the National Symposium, Dar es Salaam, 1998.

[14] J. Rugumyamheto, "Innovative Approaches to Reforming Public Services in Tanzania," Public Administration and Development, Vol. 24, 2004, pp. 437-446. doi:10.1002/pad.335

[15] C. Pollitt, C. Talbot, J. Caulfield and A. Smullen, "Agencies: How Governments do Things through Semi-Autonomous Organizations,” Macmillan: Basingstoke, 2004.

[16] B. Bana and W. McCcourt, "Institutions and Governance: Public Staff Management in Tanzania,” Public administration and development, Vol. 26, 2006, pp. 395-407. doi:10.1002/pad.423

[17] F. Ronsholt and M. Andrews, "Getting it Together or Not: An Analysisof the Early Period of Tanzania's Move Towards Adopting Performance Management Systems," International Journal of Public Administration, Vol. 28, 2004, pp. 313-336.

[18] A. Sulle, "The Application of New Public Management Doctrine in Developing World: An exploratory study of Autonomy and Control of Executive Agencies in Tanzania,” Public Administration and Development, Vol. 30, No. 5, 2010, pp. 345-354. doi:10.1002/pad.580

[19] A. Sarker, "New Public Management in Developing Countries: An Analysis of Success and Failure with Particular Reference to Singapore and Bangladesh,” International Journal of Public Sector Management, Vol. 19, No. 2, 2006, pp. 180-203. doi:10.1108/09513550610650437

[20] A. Schick, "Why Most Developing Countries Should Not Try New Zealand's Reforms,” The World Bank Research Observer, Vol. 13, No. 1, 1998, pp. 123-131. 